\title{
Efektivitas Penggunaan Peta Konsep Terhadap Hasil Belajar Siswa Kelas VII SMP Negeri 2 Ponre Kecamatan Ponre Kabupaten Bone
}

\author{
Sitti Asmah \\ Universitas Muhammadiyah Bone \\ Email: asmahrappocini@gmail.com
}

\begin{abstract}
Abstrack
This research is an experimental study aimed to determine the effectiveness of the use of the Concept Map Method on the Biology Learning Outcomes of Class VII Students at MTs Bulu-Bulu, Tonra District, Bone Regency. The research design was Posttest-Only Control Design. The population in this study were all seventh grade students of MTs Bulu-Bulu, Tonra District, Bone Regency and the sample consisted of two classes, namely class VII A as the control class and class VIIB as the experimental class. Data collection techniques are tests and documentation. The data analysis technique used is descriptive statistical analysis and inferential analysis. Based on the results of the analysis and discussion of the Effectiveness of the Use of the Concept Map Method on the Learning Outcomes of Class VII Students at MTs Bulu-Bulu, Tonra District, Bone Regency, it can be concluded that the average result of the Biology learning outcomes of students in the experimental class is 82.75 while in the control class is 82.75 . 74.76. The results of hypothesis testing by t-test, in the calculation of t-test known 3.00 and ttable 2.023 with $\mathrm{db}$ of 39 , obtained from $21+20-2$, at a significant level of $0.05(5 \%)$, so that $t$ count $>t$ table $=3.002 .023$, it can be concluded that the null hypothesis $\left(\mathrm{H}_{0}\right)$ is rejected and the alternative hypothesis $\left(\mathrm{H}_{1}\right)$ is accepted.
\end{abstract}

Keyword : Effectiveness, Concept Maps And Learning Outcomes.

\section{PENDAHULUAN}

Pendidikan di indonesia berkewajiban mempersiapkan generasi baru yang sanggup menghadapi tantangan masa depan. Sistem pendidikan di Indonesia belum mampu menjawab kebutuhan dan tantangan global untuk masa yang akan datang. Program peningkatan kualitas pendidikan yang selama ini menjadi fokus pembinaan masih menjadi masalah dalam pendidikan di Indonesia. Peningkatan kualitas pendidikan dipengaruhi oleh banyak faktor seperti kualitas guru, siswa, metode, media, bahan ajar dan sumber belajar. Diantara faktor tersebut yang paling dominan adalah faktor guru. Mengkaji

persoalan keberhasilan proses pembelajaran banyak dipengaruhi oleh variabel yang datang dari pribadi siswa sendiri, usaha guru dalam menyediakan dan menciptakan kondisi pembelajaran, serta variabel lingkungan terutama sarana dan iklim, dari tiga variabel di atas merupakan kunci keberhasilan pembelajaran ditinjau dari sudut proses. Asumsi dasar bahwa proses pembelajaran yang optimal memungkinkan hasil yang optimal pula. Ada korelasi antara proses pengajaran dengan hasil yang dicapai. Makin besar usaha untuk menciptakan kondisi proses pengajaran makin tinggi pula hasil atau produk dari pembelajaran itu.

Pendidikan pada dasarnya adalah usaha sadar untuk menumbuh kembangkan potensi sumber daya manusia peserta didik dengan cara mendorong dan memfasilitasi kegiatan belajar mereka. Dengan kata lain, pendidikan itu sangat penting untuk dilaksanakan. Salah satunya pendidikan biologi, setiap guru menginginkan proses pembelajaran yang menyenangkan dan berpusat pada siswa. Siswa antusias mengacungkan tangan untuk menjawab pertanyaan atau memberikan pendapat, bersorak merayakan keberhasilan mereka, bertukar informasi dan saling memberikan semangat. Dan tujuan akhir dari semua proses itu adalah penguasaan konsep dan hasil belajar yang memuaskan. 


\section{KAJIAN PUSTAKA Efektifitas}

Efektifitas merupakan kesesuaian antara orang yang melaksanakan tugas dengan sasaran yang dituju. Keefektifan juga dapat diartikan sebagai keadaan berpengaruh, hal bekesan, kemajuan, keberhasilan. Masalah efektifitas biasanya berkaitan erat dengan perbandingan antara tingkat pencapaian tujuan dengan rencana yang telah disususn sebelumnya, atau perbandingan dengan hasil nyata dengan hasil yang direncanakan. Berdasarkan teori system, kriteria efektifitas harus mencerminkan keseluruhan siklus input, proses, dan output. Pembelajaran dapat dikatakan efektif apabila proses pembelajaran tersebut mencapai tujuan yang di inginkan.

\section{Media Pengajaran}

Media pembelajaran merupakan salah satu penentu utama tercapainya tujuan belajar. Pada era globalisasi sekarang ini, teknologi informasi dan komunikasi terus berkembang pesat. Hal ini berdampak positif pada bidang pendidikan dengan munculnya beragam media pembelajaran yang dapat membantu siswa memahami materi pelajaran. Hal yang sama disampaikan Samsudin dan Liliawati (2011) yang menyatakan pemanfaat media yang relevan akan membuat pembelajaran lebih efektif dan efisien. Media adalah berperan penting dalam proses pembelajaran. Oleh karena itu pada tahap pemilihan media guru harus mempertimbangkan kesesuaian media dengan materi dan kondisi siswa.

\section{Hakekat Belajar}

\section{a. Pengertian Belajar}

Belajar tidak hanya mengenai bidang intelektual, akan tetapi mengenai seluruh pribadi anak. Perubahan kelakuan karena mabuk bukanlah hasil belajar. Menurut Hamalik (2005: 28) mengatakan bahwa belajar merupakan bentuk pertumbuhan dan perkembangan dalam diri seorang yang dinyatakan dalam caracara bertingkah laku yang baru berkat pengalaman dan latihan.
Belajar itu sendiri terdiri dari berbagai tipe yaitu:

1) Menghafal dalam pelajaran dengan sedikit tanpa memahami artinya, misalnya teori.

2) Memperoleh pengertian-pengertian yang sederhana, seperti kenyataan empat di tambah lima semua berjumlah Sembilan.

3) Menemukan dan memahami hubungan yang menghendaki respon-respon logis dan benar-benar psikologis.

b. Ciri-ciri Belajar

Belajar memiliki beberapa ciri, sekaligus mencerminkan perubahan yang terjadi pada diri individu. Beberapa ciriciri belajar, digambarkan sebagai berikut:

1) Adanya kemampuan baru atau perubahan-perubahan tingkah laku bersifat pengetahuan (kognitif), keterampilan (psikomotorik), maupun nilai dan sikap (afektif).

2) Perubahan itu tidak berlangsung sesaat saja melainkan menetap atau dapat disimpan.

3) Perubahan itu terjadi begitu saja melainkan harus dengan usaha. Perubahan terjadi akibat interaksi dengan lingkungan.

\section{Peta Konsep}

\section{a. Pengertian Metode Peta Konsep (Mind Mapping)}

Metode Peta Konsep (Mind Mapping) adalah metode pembelajaran yang dikembangkan oleh Tony Buzana, kepala Brain Foundation. Peta pikiran adalah metode mencatat kreatif yang memudahkan kita mengingat banyak informasi. Setelah selesai, catatan yang dibuat membentuk sebuah pola gagasan yang saling berkaitan, dengan topik utama di tengah, sementara subtopik dan perincian menjadi cabang-cabangnya (Ahamad Munjin Nasih, 2009:110-111).

\section{b. Karakteristik Metode Peta Konsep} (Mind Mapping)

Pada dasarnya metode mencatat ini, barangkat dari hasil sebuah penelitian 
tentang cara otak memperoses informasi. Semula para ilmuan menduga bahwa otak memperoses dan menyimpan informasi secara linier, seperti metode mencatat tradisional.

\section{c. Pengertian Konsep dan Peta Konsep}

Konsep atau pengertian merupakan kondisi utama ynag diperlakukan untuk menguasai kemahiran diskriminasi dan proses kognitif fundamental sebelumnya berdasarkan kesamaan ciri-ciri dari sekumpulan stimulus dan objek-objeknya. Carrol (dalam Trianto, 2011: 2) mendifinisikan konsep sebagai suatu abstraksi dari serangkaian pengalaman yang didefinisikan sebagai suatu kelompok objek atau kejadian.

Agar pemahaman terhadap peta konsep lebih jelas, maka dahar (1989) yang dikutip oleh Erman (2003), mengemukakan ciri-ciri peta konsep sebagai berikut:

1) Peta konsep (pemetaan konsep) Adalah suatu cara untuk memperlihatkan konsep-konsep dan proposisi-proposisi suatu bidang studi, apakah itu bidang studi fisika, kimia, biologi, matematika dan lain-lain.

2) Peta konsep bersifat hirarki. Bila dua atau lebih konsep digambarkan di bawah suatu konsep yang lebih inklusif, terbentuklah suatu hirarki pada peta konsep tersebut.

\section{d. Kegunaan Peta Konsep}

Dalam pendidikan, peta konsep dapat diterapkan untuk berbagai tujuan, antara lain;

1) Menyelidiki apa yang diketahui siswa.

Dengan menggunakan peta konsep, guru dapat melaksanakan apa yang telah dikemukakan di atas sehingga pada para siswa diharapkan akan terjadi belajar bermakna.

2) Mempelajari cara belajar.

Di tingkat SMP dan SMA, guru dapat memberikan tugas membaca sebuah judul dalam buku teks, kemudian mengungkapkan sari judul itu dengan membuat peta konsep. Dengan melatih mereka membuat peta konsep untuk mengambil sari dari apa yang mereka baca, baik buku teks maupun bacaan-bacaan lain. Mereka tidak dapat lagi dikatakan tidak berfikir.

3) Mengungkapkan miskonsepsi.

Dari peta konsep yang dibuat oleh para pelajar, ada kalanya ditemukan miskonsepsi yang terjadi dari dikaitkanya dua konsep atau lebih yang membentuk proposisi yang "salah". Dalam kepustakaan pendidikan sains, berbagai nama ditemukan untuk miskonsepsi.

4) Alat evaluasi.

Selama ini alat evaluasi yang dibuat oleh guru atau pelajar terutama berbentuk tes objektif atau tes esai. Walaupun cara evaluasi ini akan terus memegang peranan dalam dunia pendidikan, teknik evaluasi baru perlu dipikirkan untuk memecahkan masalah evaluasi yang kita hadapi dewasa ini. Salah satu yang disarankan ialah dengan penggunaan peta konsep yang didasarkan pada tiga gagasan dalam teori ausubel, (Novak: 2005).

e. Kelebihan dan Kekurangan dalam membuat Peta Konsep

Kelebihan Peta Konsep bagi siswa (Haris: 2005) adalah sebagai berikut:

1) Pemetaan konsep merupakan cara belajar yang mengembangkan proses belajar yang bermakna, yang akan meningkatkan pemahaman siswa dan daya ingat belajarnya.

2) Dapat meningkatkan keaktifan dan kreatifitas berfikir siswa, pada giliranya akan menimbulkan sikap kemandiria belajar yang lebih pada siswa.

Kelemahan Peta Konsep bagi siswa adalah sebagai berikut:

1) Perlunya waktu yang cukup lama untuk menyusun peta konsep, sedangkan waktu yang tersedia terbatas

2) Sulit menentukan konsep-konsep yang terdapat pada materi yang dipelajari.

\section{f. Penerapan Strategi Peta Konsep dalam Pembelajaran}


Strategi merupakan sebuah metode yang memungkinkan penyediaan beberapa solusi dari suatu masalah dan memberikan beberapa informasi. Strategi merupakan pola-pola umum kegiatan guru dan siswa dalam perwujudan kegiatan belajar mengajar untuk mencapat tujuan yang telah digariskan. Menurut (Arif Priadi: 2009) Strategi pembelajaran Peta Konsep (mind mapping) merupakan strategi pembelajaran yang dapat menguatkan siswa untuk menghadapi persoalan dengan langkah penyelesaian yang sistematis, yaitu: memahami masalah, menyusun rencana, melaksanakan rencana, dan memeriksa kembali, sehingga persoalan yang dihadapi dapat diatasi.

\section{Hasil Belajar}

Berdasarkan pengertian hasil belajar di atas, disimpulkan bahwa hasil belajar adalah kemampuan-kemampuan yang dimiliki siswa setelah menerima pengalaman belajarnya. Kemampuan-kemampuan tersebut mencakup aspek kognitif, afektif, dan psikomotorik. Hasil belajar dapat dilihat melalui kegiatan evaluasi yang bertujuan untuk mendapatkan data pembuktian yang akan menunjukkan tingkat kemampuan siswa dalam mencapai tujuan pembelajaran. faktorfaktor yang mempengaruhi belajar. Hasil belajar sebagai salah satu indikator pencapaian tujuan pembelajaran di kelas tidak terlepas dari faktor-faktor yang mempengaruhi hasil belajar itu sendiri.

\section{METODE PENELITIAN Jenis Penelitian}

Jenis penelitian ini adalah penelitian True Experimental Design yaitu jenis penelitian eksperimen yang dianggap baik karena sudah memenuhi persyaratan berupa adanya kelompok lain yang tidak dikenal eksperimen dan ikut mendapatkan pengamatan, Sedarmayanti (2006: 35).

\section{Populasi dan Sampel}

\section{Populasi}

Pada hakekatnya yang dimaksud dengan Populasi merupakan faktor sangat penting dalam suatu penelitian yang harus diperhatikan. Sebab hal ini menjadi kunci terhadap segala rangkaian kegiatan penelitian itu. Sutrisno Hadi (2004-39) menyatakan "Populasi adalah seluruh penduduk yang dimaksudkan untuk diselidiki atau universum". Populasi adalah jumlah keseluruhan unit analisis yang akan diselidiki karakteristik atau ciri-cirinya.

Adapun populasi penelitian ini adalah keseluruhan siswa kelas VII di MTs BuluBulu Kecamatan Tonra Kabupaten Bone. Untuk jelasnya dapat dilihat dalam tabel 3.1.

Tabel 3.1. Populasi Penelitian

\begin{tabular}{|c|c|c|c|c|}
\hline \multirow{2}{*}{ No. } & \multirow{2}{*}{ Kelas } & \multicolumn{2}{|c|}{ Jenis Kelamin } & \multirow{2}{*}{ Jumlah } \\
\cline { 3 - 4 } & & Laki-laki & Perempuan & \\
\hline 1. & VII A & 13 & 8 & 21 \\
\hline 2. & VII B & 13 & 7 & 20 \\
\hline \multicolumn{2}{|c|}{ Jumlah } & 26 & 15 & 41 \\
\hline
\end{tabular}

Sumber : MTs Bulu-Bulu Kecamatan Tonra

\section{Sampel} tahun ajaran 2016/2017.

Jumlah sampel dalam penelitian ditetapkan sebanyak 41 siswa. Sampel penelitian adalah siswa kelas VII A sebagai kelas eksperimen dan siswa kelas VII B sebagai kelas kontrol. Untuk lebih jelasnya mengenai sampel penelitian dapat dilihat pada tabel berikut: 
Tabel 3.2 Sampel Penelitian

\begin{tabular}{|c|c|c|c|c|}
\hline \multirow{2}{*}{ No. } & \multirow{2}{*}{ Kelas } & \multicolumn{2}{|c|}{ Jenis Kelamin } & \multirow{2}{*}{ Jumlah } \\
\cline { 3 - 5 } & Laki-laki & Perempuan & \\
\hline 1. & $\begin{array}{c}\text { VII A } \\
\text { (Kelas } \\
\text { Kontrol) }\end{array}$ & 13 & 8 & 21 \\
\hline 2. & $\begin{array}{c}\text { VII B } \\
\text { (Kelas } \\
\text { Eksperimen) }\end{array}$ & 13 & 7 & 20 \\
\hline \multicolumn{2}{|c|}{ Jumlah } & 26 & 15 & 41 \\
\hline
\end{tabular}

Sumber : MTs Bulu-bulu Kecamatan Tonra.

\section{Variabel Penelitian}

Variabel penelitian pada dasarnya adalah segala sesuatu yang terbentuk apa saja yang ditetapkan oleh peneliti untuk dipelajari sehingga diperoleh informasi tentang hal tersebut, kemudian ditarik kesimpulannya.Variabel dalam penelitian ini yaitu: Variabel bebas (Independen variable) yaitu faktor yang mempengaruhi variabel terikat, sedangkan variabel terikat (Dependen variable) yang mempengaruhi variabel bebas.

Adapun variabel-variabel yang penulis gunakan adalah sebagai berikut:

1. Variabel bebas, yaitu Metode Peta Konsep merupakan variabel bebas (independent variabel), yang akan digunakan sebagai perlakuan (treatment) dikelas eksperimen.

2. Variabel terikat, yaitu hasil belajar dalam mata pelajaran biologi.

\section{Desain Penelitian}

Desain penelitian yang digunakan dalam penelitian ini adalah Posttest Only Control Group Design yang terdiri dari kelas eksperimen dan kelas kontrol. Model desain tersebut dapat dilihat pada gambar dibawah ini :

Gambar 3.1 Desain Penelitian

\begin{tabular}{|lll|}
\hline $\mathrm{R}_{1}$ & $\mathrm{X}$ & $\mathrm{O}_{1}$ \\
$\mathrm{R}_{2}$ & - & $\mathrm{O}_{2}$ \\
\hline
\end{tabular}

Keterangan :

$\mathrm{R}_{1} \quad$ : kelompok eksperimen
$\mathrm{R}_{2} \quad$ : kelompok kontrol

$\mathrm{O}_{1} \quad$ : hasil posttest pada kelas eksperimen

$\mathrm{O}_{2} \quad$ : hasil posttest pada kelas kontrol

X : perlakuan terhadap kelompok eksperimen yaitu dengan menerapkan metode Peta Konsep.

- $\quad$ : tidak ada perlakuan (Sugiyono, 2012)

\section{Instrumen Penelitian}

Instrumen penelitian adalah alat yang digunakan untuk menyaring informasi yang dapat menggambarkan variabel-variabel penelitian. Suatu instrumen harus teruji validitas dan realibilitasnya agar dapat memperoleh data yang valid dan reliabel. Pada penelitian ini, instrumen yang digunakan peneliti yaitu berupa tes hasil belajar. Peneliti mengumpulkan data dari hasil belajar siswa selama proses pembelajaran berlangsung dikelas kelas VII diMTs Bulu-Bulu Kecamatan Tonra Kabupaten Bone.

\section{Teknik Pengumpulan Data}

Teknik pengumpulan data yang digunakan dalam penelitian ini yaitu :

1. Tes

Tes adalah suatu instrumen penelitian yang digunakan untuk mengumpulkan data tentang tingkat atau hasil belajar siswa.

2. Dokumentasi

Dokumentasi adalah suatu teknik pengumpulan data dengan menghimpun dan menganalisis dokumen-dokumen baik berupa dokumen tertulis, gambar maupun elektronik.

\section{Teknik Analisis Data}

Data yang diperoleh dari sampel melalui instrument yang dipilih akan digunakan untuk menjawab pertanyaan penelitian atau pengujian hipotesis. Oleh karena itu data akan perlu diolah dan dianalisis agar mempunyai makna guna pemecahan masalah tersebut. Pengelolah data hasil belajar dalam penelitian ini digunakan 
dengan teknik Statistik Deskriptif dan Statistik Inferensial.

\section{Analisis statistik deskriptif}

Data yang terkumpul pada penelitian ini dianalisis dengan menggunakan teknik analisis statistik deskriptif yang digunakan untuk mendeskripsikan karakteristik distribusi skor hasil belajar Biologi.

2. Teknik Analisis Statistik Inferensial

Analisis statistic inferensial digunakan untuk menguji hipotesis penelitian yang diajukan.

\section{HASIL PENELITIAN dan PEMBAHASAN \\ Pembahasan}

Berdasarkan hasil uji-t yang telah diungkapkan di atas, diperoleh bahwa terdapat perbedaan yang signifikan pada hasil belajar biologi antara kelompok siswa yang dibelajarkan menggunakan metode pembelajaran Peta Konsep dengan kelompok siswa yang dibelajarkan tanpa menggunakan metode pembelajaran Peta Konsep pada siswa kelas VII di MTs Bulu-Bulu Kecamatan Tonra Kabupaten Bone. Hasil analisis deskriptif yang telah dilakukan juga menunjukkan bahwa, skor hasil belajar kelompok eksperimen berada pada kualifikasi tinggi, sedangkan skor hasil belajar pada kelompok kontrol berada pada kualifikasi sedang.

Tujuan dalam penelitian ini yaitu untuk mengetahui Efektifitas Penggunaan Metode Peta Konsep Terhadap Hasil Belajar Biologi Siswa Kelas VII di MTs Bulu-Bulu Kecamatan Tonra Kabupaten Bone yang digunakan pada kelas eksperimen ternyata memberikan hasil lebih baik terhadap hasil belajar Biologi dibandingkan dengan pemberian model pembelajaran konvensional pada kelas kontrol. Berdasarkan hasil penelitian di kelas VIIB sebagai kelas eksperimen dengan menggunakan metode pembelajaran Peta Konsep lebih baik dan memberikan semangat belajar bagi siswa dibandingkan dengan menggunakan model pembelajaran konvensional yang cenderung membuat siswa jenuh di dalam kelas dan bahkan suka bermain ketika guru menjelaskan.

Berdasarkan hasil penelitian dan analisis data dapat disimpulkan bahwa hasil rata-rata pada kelas eksperimen sebesar 82,75 dengan standar deviasi 8,65. Sedangkan pada kelas kontrol diperoleh nilai rata-rata sebesar 74,76 dengan standar deviasi 9,14. Untuk hasil pengujian hipotesis yang menggunakan uji-t diperoleh nilai untuk thitung adalah 3,0 sedangkan untuk nilai $t_{\text {tabel }} 2,023$. Dari hasil analisis tersebut dapat dikatakan bahwa thitung $\geq t_{\text {tabel }}(3,00 \geq 2,023)$ dengan taraf signifikan $5 \%$ dan dk $(21+20-2=39)$ maka terdapat perbedaan antara kelas eksperimen dan kelas kontrol. Dengan demikian $\mathrm{H}_{1}$ diterima dan $\mathrm{H}_{0}$ ditolak. Dari hasil tersebut maka dapat disimpulkan bahwa "Penggunaan Metode Peta Konsep Efektif digunakanTerhadap Hasil Belajar Biologi Siswa Kelas VII di MTs Bulu-Bulu Kecamatan Tonra Kabupaten Bone".

\section{SIMPULAN}

Berdasarkan hasil analisis dan pembahasan Efektivitas Penggunaan Metode Peta Konsep Terhadap Hasil Belajar Siswa Kelas VII di MTs Bulu-Bulu Kecamatan Tonra Kabupaten Bone, maka dapat disimpulkan bahwa hasil rata-rata hasil belajar Biologi siswa pada kelas eksperimen yaitu 82,75 sedangkan pada kelas kontrol yaitu 74,76 .

Berdasarkan analisis inferensial, dengan uji $t$ di dapatkan nilai $t_{\text {hitung }} \geq \mathrm{t}_{\text {tabel }}, 3,00$ $\geq 2,023$ dengan taraf signifikan 0.05 , sehingga $\mathrm{H}_{1}$ diterima dan $\mathrm{H}_{0}$ ditolak, yang berarti bahwa "Penggunaan Metode Peta Konsep Efektif digunakanTerhadap Hasil Belajar Biologi Siswa Kelas VII di MTs Bulu-Bulu Kecamatan Tonra Kabupaten Bone".

Saran

Berdasarkan dari kesimpulan tersebut maka peneliti menyarankan, sebaiknya guru meggunakan model pembelajaran yang sesuai sehingga proses belajar mengajar di kelas 
menjadi efektif dan tidak membuat siswa merasa bosan. Selain itu, metode pembelajaran Peta Konsep (Mind Mapping) dapat memberikan rangsangan siswa untuk mengikuti kegiatan belajar di kelas dan menumbuhkan partisipasi belajar dan keaktifan siswa untuk mengikuti pelajaran dari awal sampai akhir pembelajaran. Guru adalah faktor penting dalam menciptakan pembelajaran yang inovatif untuk meningkatkan kualitas SDM. Untuk guru, hendaknya menggunakan model-model inovatif dalam setiap pembelajaran, sehingga siswa akan merasa lebih tertarik dan terlibat lebih aktif selama proses pembelajaran berlangsung.

\section{DAFTAR PUSTAKA}

Ahamad Munjin Nasih, dan Lilik Nur Kholidah, 2009. Metode Dan Teknik Pembelajaran Pendidikan Agama Islam. Bandung: PT Refika Aditama.

Arif Priadi, 2009. Teori-Teori Belajar \& Pembelajaran, Jakarta: Penerbit Erlangga

Arikunto,Suharsimi.2010. Prosedur

Penelitian Suatu Pendekatan Praktis. Jakarta: Rineka Cipta.

Arrends, 2007. Desain Model Pembelajaran Inovatif. Jakarta ; Penerbit Kencana.

Bahar Ahmad, 2007. Psikologi Pendidikan. Pustaka Nartiana. Bandung.

Depdikbud. 2015. Pendidikan Nasional. Jakarta: Katalog Klode Putra Timur.

Dimyanti dan Mudjiono, 2006. http://eka mer dekawati.blogspot.co.id/2017/03/met ode-penelitian-korelasional.html diakses tanggal 3 januari 2017

Erman, Suherman. 2003. Strategi Belajar dan Mengajar Biologi. Jakarta: Departemen Pendidikan dan Kebudayaan Direktorat Jendral Pendidikan Dasar dan Menengah.

Hadi, Sutrisno. 2004. Metodologi Penelitian. Balai Pustaka. Jakarta

Hamalik, Oemar. 2005. Pendidikan Guru Berdasarkan Pendekatan

Kompetensi. Bandung: Rosdakarya.
Haris. 2005. Peningkatan Hasil Belajar Matematika melalui Penerapan Metode Peta Pikiran (Mind Mapping) pada Siswa Kelas I SLTP Negeri 3 Makassar. Skripsi. FMIPA UNM. Makassar: Tidak diterbitkan.

Hasibuan J. 2008. Proses Belajar Mengajar Keterampilan Dasar. Remaja Karya Bandung.

Nana Sudjana, 2009. Penilaian Hasil Proses Belajar Mengajar, (Bandung : PT. Remaja Rosdakarya.

Nasution, S. 2002. Didaktik Asas-asas Mengajar. Jakarta: Andi Offset.

Nuryani Y. Rustaman, dkk. (2003). Strategi Belajar Mengajar Biologi. Bandung: FMIPA UPI

Peorwadarminta WJS. 2006. Kamus Umum Bahasa Indonesia. Bina Aksara. Jakarta,

Sudiardjo, Wibowo. 2009. Pendekatan Keterampilan Proses. PT. Gramedia. Jakarta.

Sugihartono, dkk. 2007. Model-model Pembelajaran Sains. Yogyakarta: Pusat Pengembangan Penataran Guru (PPPG).

Sugiyono. 2012. Metode Penelitian Bisnis. Bandung: Alfabeta.

Suwarno, W. 2007. Dasar-Dasar Ilmu Pendidikan. Yogyakarta: Ar-Ruzz Media.

Trianto, 2011. Mendesain Model Pembelajaran Inovatif Progresif : konsep landasan dan implementasinya pada kurikulum tingkat satuan pendidikan ( Jakarta ; kencana.

Undang-undang No 20 Tahun 2003 Tentang Sistem Pendidikan Nasional 